\title{
Estimating Ground Water Recharge using Flow Models of Perched Karstic Aquifers
}

\author{
by Menachem Weiss ${ }^{1}$ and Haim Gvirtzman ${ }^{2}$
}

\begin{abstract}
The fraction of rain that is annually recharged to ground water is a function of the transient quantities of precipitation (wet vs. dry years) as well as other meteorological and geologic factors, and thus it is very difficult to estimate. In this study, we have used long records (20 to 30 years) of precipitation and spring discharge to reconstruct the transient character of yearly recharge. These data sets were used to calibrate numerical ground water flow models on the less than $3 \mathrm{~km}^{2}$ scale for four separate perched karstic aquifers in the Judean and Samarian Mountains of Israel. The stratification and karstic character of the local carbonate rock aquifers cause ground water to flow through discrete dissolution channels and to discharge at isolated springs. An innovative, dual-porosity approach was used where a finite-difference solution simulates flow in the rock matrix, while the karstic channels are simulated using computationally simple drains. Perched conditions are also simulated innovatively using MODFLOW by treating the bottom unsaturated layer as if it is saturated, but by assuming zero pressure head throughout the "unsaturated" layer. Best fitting between measured and computed spring hydrograph data has allowed us to develop a set of empirical functions relating measured precipitation to recharge to the aquifer. The generic methodology presented gives insight into the suspected changes in aquifer recharge rates between particularly wet or dry years.
\end{abstract}

\section{Introduction}

Researchers have been troubled with finding a reliable technique for estimating aquifer recharge from precipitation and evaporation data. The precipitationrecharge relation is complicated due to temporal and spatial variations (Nimmo et al. 2005). Recharge estimation can be divided into two general techniques: (1) forward water balance calculations, whereby recharge is estimated by calculating the difference between measured precipitation and evapotranspiration, and (2) inverse calibration, whereby recharge is estimated during calibration to heads and ground water flow rates.

Karstic channeling complicates the estimation of a precipitation-recharge relation since the channels

${ }^{1}$ Corresponding author: Institute of Earth Sciences, Hebrew University of Jerusalem, Givat Ram, Jerusalem 91904, Israel; 9722-6442520; fax 972-2-6442529; menachemw@water.gov.il

${ }^{2}$ Institute of Earth Sciences, Hebrew University of Jerusalem, Givat Ram, Jerusalem 91904, Israel.

Received January 2007, accepted June 2007.

Copyright (c) 2007 The Author(s)

Journal compilation (c) 2007 National Ground Water Association. doi: $10.1111 / j .1745-6584.2007 .00360 . x$ supplying recharge to the ground water system are somewhat isolated from the evapotranspiration processes occurring in the surrounding matrix. The thickness of the unsaturated zone also affects the recharge-precipitation ratio since the presence of a deep water table allows for unsaturated water or vapor flux to occur in either vertical direction depending on the surface conditions (Scanlon et al. 1997).

For numerical models that use hydraulic-head measurements for calibration, a strong inverse correlation between recharge and hydraulic conductivity is created, therefore only allowing these parameters to be estimated together as a ratio $(R / K)$ (Scanlon and Cook 2002). When aquifer flux measurements are available, however, such as from spring discharge data or field measurements of soil saturation, the recharge rate can be constrained independently (Sanford 2002). Flint et al. (2002) showed a comparison between different methods of estimating aquifer recharge and concluded that characterizing recharge requires careful consideration of the spatial scale.

The Yarqon-Taninim aquifer is one of Israel's most important resources of fresh water, providing the country with approximately 330 million cubic meters of fresh 
water per year (Hydrology Service 2005). Previous research conducted on the Yarqon-Taninim aquifer resulted in a series of empirical equations relating transient precipitation and recharge. Guttman and Zuckerman (1995) and Guttman (2000) summarized these studies and suggested precipitation-recharge functions for the Yarqon-Taninim aquifer according to the following three linear equations:

$$
\begin{aligned}
& R=0.45(P-0.18) \quad \text { when } P<0.6 \mathrm{~m} \\
& R=0.88(P-0.41) \quad \text { when } 0.6 \mathrm{~m}<P<1.0 \mathrm{~m} \\
& R=0.97(P-0.463) \quad \text { when } P>1.0 \mathrm{~m}
\end{aligned}
$$

where $R$ is yearly recharge and $P$ is yearly precipitation (in meters). Accordingly, since precipitation ranges between 0.25 and $1.35 \mathrm{~m}$, ground water recharge in the study area will range between $6 \%$ and approximately $65 \%$ of the precipitation. Our goal here is to test and refine these equations using numerical ground water flow models calibrated against a 20 to 30 year record of rainfall and spring discharge. We are fortunate to have a long and relatively complete database of spring discharge data from a number of sites, which allows us to calibrate our numerical models primarily with the recharge parameter. The four study areas presented here were chosen after a careful selection process from approximately 100 potential sites in Israel because the geologic structure and the spring recharge area are particularly well defined.

\section{Hydrogeologic Setting and Conceptual Model Development}

The Yarqon-Taninim aquifer is composed of the middle- to late-Cretaceous Judea Group, which traditionally is divided into 12 different formations (Arkin 1976; Sneh et al. 1998; Shachnai 2000) (Figure 1). The Judea Group rocks are mainly limestone and dolomite, with much smaller amounts of marl and chalk. The limestone and dolomite rocks have relatively high hydraulic conductivity due to extensive fracturing and karst channeling, while the marl and chalk rocks are generally unfractured and with a much lower hydraulic conductivity. Researchers have divided the Judea Group aquifer into two separate limestone/dolomite subaquifers divided by the Moza Formation chalk/marl aquitard (Mercado 1980; Bida 1986; Guttman 1986), although other, deeper subaquifers exist locally below relatively impermeable layers within the Soreq Formation. The relatively impermeable aquitards do not totally prevent water from being transferred between the subaquifers. In some places, water is transferred between the subaquifers directly because of a lateral facies change in which the aquitard is missing. In other places, severe fracturing affects the chalk, thereby allowing the aquifers above and below to be hydrologically connected.

The process of karstification in the Judea Group is well documented (Frumkin 2002; Frumkin and Fischhendler 2005), and the conduits associated with this process are exploited by ground water as preferential flow pathways. The formations within the Judea Group noted for their karst and intense fracturing are the Amminadav and

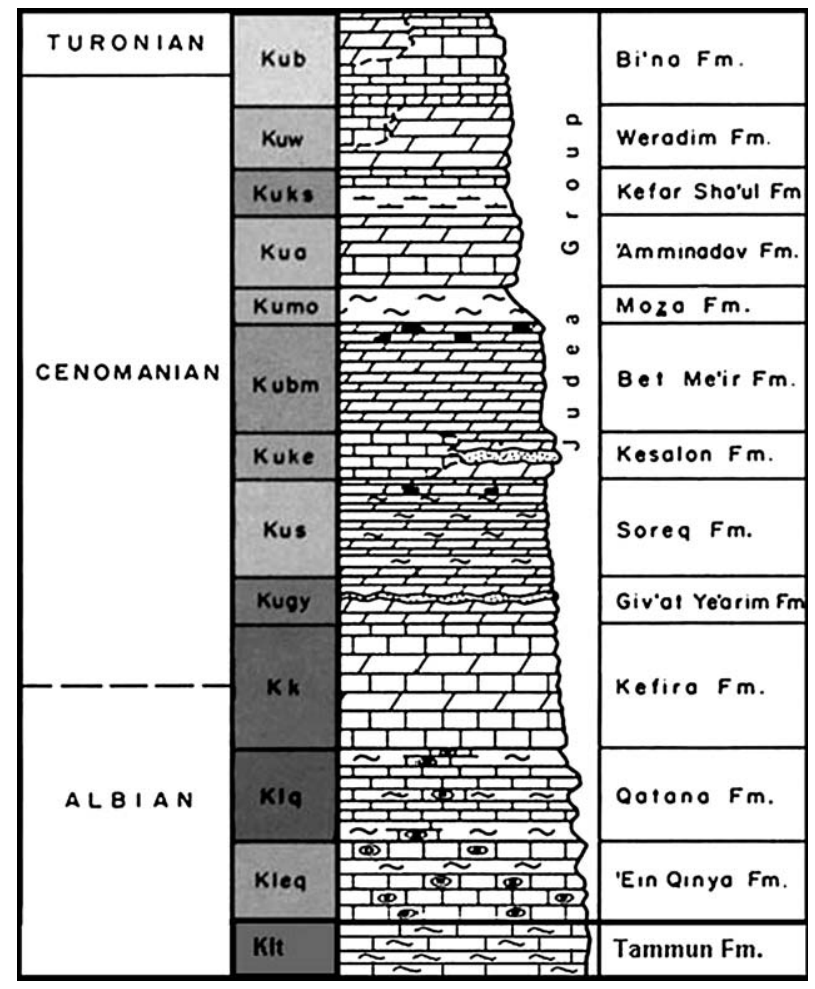

Figure 1. The Judea Group stratigraphic column of major rocks exposed in the study area (Arkin 1976).

Kefira Formations (Bar-Mathews and Ayalon 1988; Figure 1).

The study region is located in a semiarid Mediterranean climate, with an average annual temperature of between $15^{\circ} \mathrm{C}$ and $18^{\circ} \mathrm{C}$ (Amit et al. 2002). The average precipitation rate in the region is approximately $550 \mathrm{~mm} /$ year (Figure 2), with rainfall events being brief and infrequent, generally between November and March (Gvirtzman 2002). The hilly landscape is rocky and scarcely vegetated (except where terraces have been artificially cultivated for agriculture), thereby limiting the effects of plant transpiration. Very little $(0.5 \%$ to $3.0 \%)$ surface rainfall goes to overland flow (Hydrology Service 2001). Therefore, rainfall has two general pathways (Figure 3): (1) evapotranspiration and (2) recharge to the perched aquifer, whose thickness varies significantly between summer and winter, as suggested by the seasonal variations in spring discharge. From the perched aquifer, ground water flows in two directions: (1) emergence through distinct springs and (2) deeper infiltration to the lower aquifer.

\section{Water Mass Balance}

Four different sites within the Yarqon-Taninim aquifer were chosen for building conceptual and numerical hydrogeological models (Figure 2). The four study areas were chosen because they each have a relatively long and complete record of rainfall data from nearby meteorological stations and a single spring at a distinct location where accurate discharge measurements have been made over a relatively long and continuous time span. Most importantly, due to each of the study area's unique geologic 


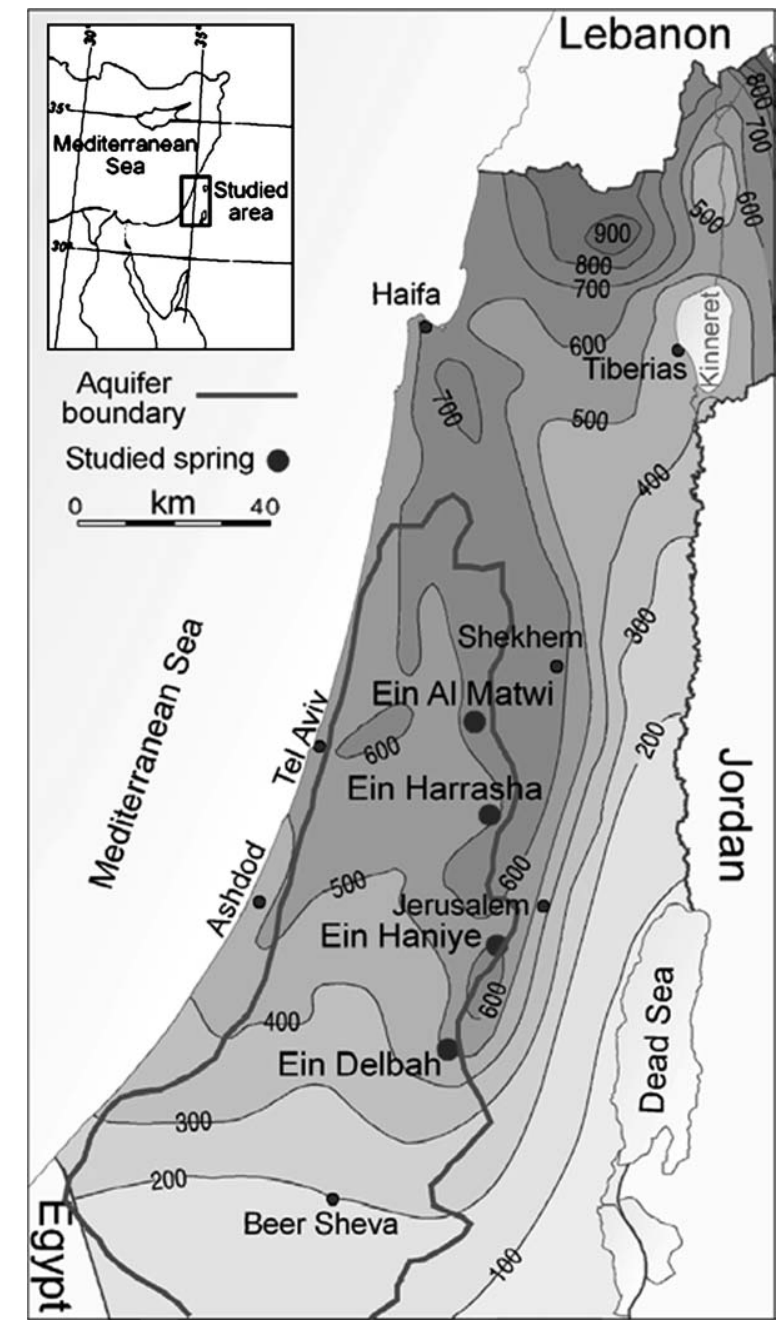

Figure 2. Regional map showing the four study areas and the spatial distribution of yearly rainfall (Gvirtzman 2002).

setting, the recharge areas for each of the springs are very well defined. Figure 4 shows the geology and topography at one of the modeled areas (Ein Al Matwi), which exemplifies the unique hydrologic setting. Similar figures for the other three areas, as well as their water mass balance calculations, are included in the electronic supplementary material (Figures S1 through S3 ).

Table 1 shows the details of each of the four springs. The first three (Ein Al Matwi, Ein Haniye, and Ein Delbah) all discharge from the upper perched aquifer (Amminadav Formation; Figure 1). The fourth spring (Ein Harrasha) discharges from the lower part of the aquifer (Kefira Formation; Figure 1) and shows very different hydrological characteristics. The reader is informed that the word "Ein" in Hebrew and Arabic means "spring."

\section{Ein Al Matwi}

The discharge point is located in the Samarian Hills at an elevation of $375 \mathrm{~m}$ above sea level. The spring is located at the contact between the Amminadav Formation (karstic limestone perched aquifer) on top and the Moza Formation (relatively impermeable marl aquitard) below (Figure 4). The geologic layering dips distinctly to the northwest and exposures of the geologic contact between the two formations can be observed on the southwestern, western, northern, and eastern sides of the hill, defining the recharge area and model boundaries at these locations. The southeastern border of the model is not defined by the formation contact but rather is defined along a topographic low separating the site (and the geologic strata) from another hill to the south. Another spring discharges at the northwest corner of the hill to the south, which implies a flow divide between these two hills. Furthermore, the dip of the geologic layers becomes flatter toward the southeast, further suggesting a ground water flow divide in this area allowing for the model boundary to be defined.

Our reconstruction of the recharge area is supported by the fact that rainfall stations in the area show an average rainfall of approximately $0.650 \mathrm{~m} /$ year (Figure 5) and, based on the aforementioned equations (Guttman 2000) relating precipitation to recharge, this corresponds to an average recharge of $0.232 \mathrm{~m} / \mathrm{year}$. This value applied evenly over the defined recharge area of the system $\left(2.006 \mathrm{~km}^{2}\right)$ corresponds to an annual volumetric recharge of $465,363 \mathrm{~m}^{3}$. Since the spring has a mean discharge of $94,595 \mathrm{~m}^{3} / \mathrm{year}$, this suggests that approximately $20 \%$ of the overall recharge to the subsurface is discharged to the spring and the remaining $80 \%$ penetrates the aquitard and infiltrates to the lower aquifer (overland surface flow is insignificant). As will be seen, this ratio is relatively consistent for all of the study areas and similar to previously published estimates, implying that the recharge areas have been well defined (Table 1).

Table 1 shows the ratio of the average yearly spring discharge to the overall assumed recharge for each of the study areas. The results show that the percentage of recharge water discharging from the springs ranges between $18 \%$ and $33 \%$ with the remaining water penetrating to the lower aquifer.

Burg (1998) estimated that approximately $6 \%$ to $19 \%$ of the total potential recharge to the lower aquifer is discharged via the various perched springs. However, that work was based on only one spring discharging from the Amminadav-Moza Formation contact and four other springs from dolomite and chalk perched aquifers in the northern part of Israel, which have different hydrological flow characteristics than the springs discussed here. Furthermore, Burg's work was based on spring discharge data from only 2 (atypically wet) years, while the present study is based on 20 to 30 years of data. Because the formations within the Judea Group most noted for their intense fracturing and karst are the Amminadav and Kefira Formations (Bar-Mathews and Ayalon 1988), it is not surprising that the springs studied here have higher percentages of recharge to the lower aquifer than the springs from Burg's work.

\section{Numerical Model Development}

For our scale of study $\left(0.5\right.$ to $\left.2.5 \mathrm{~km}^{2}\right)$, we view the flow system as having two major components: (1) the rock matrix and relatively small fractures, which together can be modeled as an equivalent porous media, and (2) 


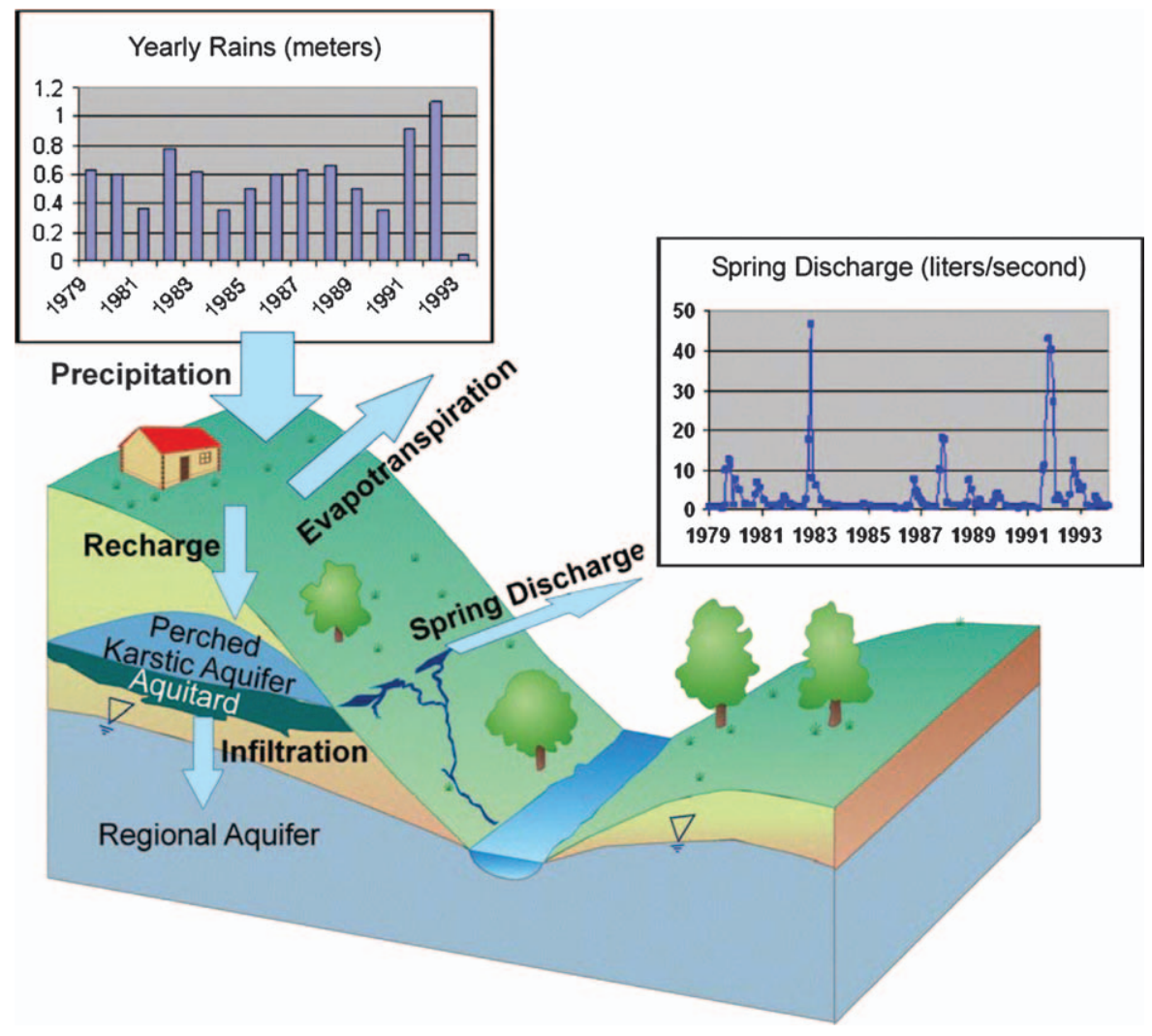

Figure 3. A conceptual model showing water flow directions: The fraction of rainfall that is not evapotranspirated replenishes the perched aquifer, which subsequently continues either as spring discharge or as seepage to the deeper aquifer. The resulting numerical ground water flow model is calibrated by both the rainfall data (using precipitation-recharge relationships) and the spring discharge data. Modified from Fetter (1988).

a well-developed network of karst conduits, which provide a high percentage of the total flow in the model. In this case, the application of a discrete fracture model is difficult because of the lack of field data regarding the fracture networks. In contrast, using a purely porous media approach would be conceptually incorrect considering the obvious karstic channel flow at the study area. Because of this, we have chosen a dual-porosity approach where flow is simulated both in the rock matrix and in the karst network. In such a case, it would be ideal to know the transient influence of each of the two flow elements (matrix and karst) on the overall spring hydrograph. Padilla et al. (1994) have shown how a detailed analysis of the recession portions of spring hydrograph curves can provide important information regarding the storage properties of each of the aquifer components (matrix as base flow, and karst/fractures as quick flow). Work by Amit et al. (2002) included quantitative assessments of the recession curves from six springs discharging in Israel. Their results showed that the ratio between the maximum storage volume in the rock matrix to the overall maximum storage of the rock matrix and karst conduits and fractures was generally greater than 0.8 . Unfortunately, translating the storage volume calculations from recession curves into actual flow information requires an assumption that the base flow and quick flow really represent isolated porous flow and karst conduit flow, respectively. Worthington (2003) showed that although the rock matrix may provide more than $90 \%$ of the aquifer storage volume, more than $90 \%$ of the flow occurs in the karst conduits and fractures. Well drilling in the Yarqon-Taninim aquifer uses video-log equipment in order to focus on perforated sections opposite karst conduits and openings to achieve the highest possible well yields. Therefore, it is the karstic network of channels, dissolution openings, and subterranean caverns that provide the majority of the flow in the Yarqon-Taninim aquifer (Gvirtzman 2002). Our dual-porosity model, therefore, cannot incorporate the details regarding the base flow and quick flow components of the spring hydrographs. Rather, the overall spring discharge must be regarded as a flow-composite coming from storage within both the surrounding rock matrix and the karst conduits.

Finite-difference numerical ground water flow models were developed for each of the four study areas using the MODFLOW 2000 code (Harbaugh et al. 2000) on the Groundwater Modeling System platform version 5.1. The original Block-Centered Flow Package was used for simulating flow in the rock matrix. This package solves the governing equation for ground water flow through anisotropic and heterogeneous porous media in three dimensions under transient saturated conditions. In addition, the Drain Package module of MODFLOW was used for simulating flow through the karstic channels. A simulated drain removes water from the aquifer at a rate proportional to the height of the surrounding water table above 




Figure 4. Geologic and topographic map of the area surrounding the spring Ein Al Matwi. Ground elevations are in meters above sea level. Formation symbols are defined in Figure 1. The black line defines the recharge area and model boundaries.

the drain. No water removal occurs if the height of the surrounding water table drops below the drain elevation.

For each of the models, a grid size of 50 rows, 50 columns, and 2 layers was constructed, where the upper layer consists of active cells and the bottom layer has inactive cells and is used to specify a constant-head boundary. Figure 6 shows a map view of one of the modeled areas (Ein Al Matwi; see also Figure 4). This resulted in individual cell sizes ranging from approximately 24 to $78 \mathrm{~m}$ in length or width. The upper layer represents the perched karstic aquifer in each model and the lower layer represents the lower, unsaturated layer. The relatively impermeable aquitard is not simulated as a separate model layer because we assume that its horizontal flow and storage effects are negligible. In this quasi-threedimensional approach, the hydraulic properties of the aquitard are represented in the numerical model by the parameter VCONT (leakance), which is the aquitard's vertical hydraulic conductivity divided by its thickness (McDonald and Harbaugh 1988).

No flow boundary conditions were assigned to the entire two-dimensional (2D) circumference of the model except for the area surrounding the simulated spring where a constant-head boundary was assigned (in the upper layer only). In each model, the base of the upper layer dips slightly toward the spring according to the measured field data. In each of our case studies, at some point upgradient, the aquifer base either becomes horizontal or dips in the opposite direction of the spring. This phenomenon gives credence to the no flow boundaries assigned at these locations. The constant-head values were assigned according to the observed locations where the springs emerge ( $0.2 \mathrm{~m}$ above the base elevation).

As noted above, the porous media below the aquitard is unsaturated, which creates challenging modeling conditions for MODFLOW since MODFLOW is generally limited to saturated conditions. We have implemented a novel approach for modeling perched aquifers with MODFLOW. The entire bottom layer of each model (representing the unsaturated zone between the aquitard base and the underlying regional aquifer, and the regional aquifer itself) is in fact an inactive layer and is modeled as a specified head boundary with each cell having a specified head equal to that cell center's elevation. This assignment forces the model to remove water from the perched aquifer system according to an approximation of the lower layer as being unsaturated with pressure heads equal to zero. The specified head boundary condition throughout the lower layer allows us to calculate the volume of water that enters the lower regional aquifer below the perched zone (Figure 3).

The upper boundary of each model was specified flow (recharge). The models simulate a perched aquifer where cells in the active layer have the potential to convert between being wet and dry. The parameters that define the criteria for whether or not a cell in the active layer will be wet or dry were adjusted on a trial and error basis to obtain stable solutions and efficient convergence. Recharge was applied to the uppermost active cell. Recharge applied to dry (inactive) cells in the upper layer 


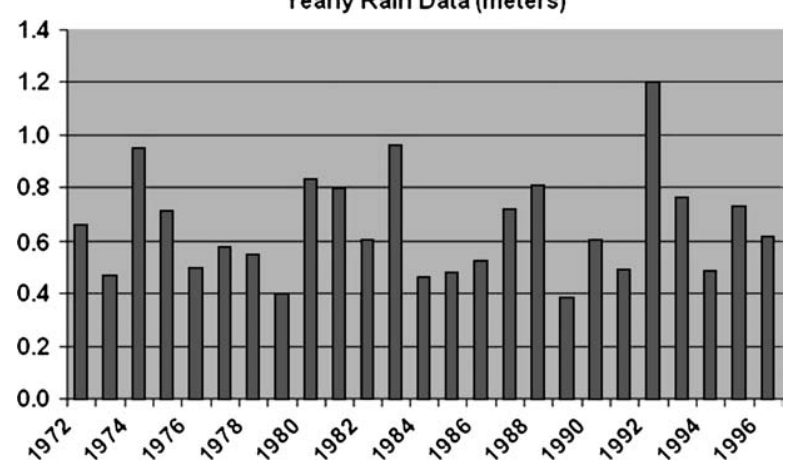

Figure 5. Yearly precipitation at Ein Al Matwi.

was assumed to penetrate to the lower regional aquifer. This assumption was required for calibrating flow in the perched aquifer and maintaining the overall mass water balance. Conceptually, we attribute nonmodeled karst as being the mechanism for water to bypass the overlying dry material and enter the lower regional aquifer. Recharge applied directly to the constant-head cells, representing the springs, was assumed to enter into the modeled perched aquifer.

As a result of the no flow boundaries assigned to the outer boundaries of the model, there was a tendency during many of the simulations for some cells along the circumference of the model domain to become flooded. The implication of this is that hydraulic heads become relatively high in the rock matrix, inducing ground water flow from the matrix to the nearby karstic channels. Regardless, the conceptual model setup is sound because of the stratigraphic dip toward the spring and the resulting water table slope toward the spring, which causes water flow lines to be parallel to the no flow boundaries. Furthermore, the modeling simulations show flooding in particular in the cells surrounding the spring outlet, and in the field we commonly observed ground water seepage in the areas near the spring.

The Drain Package within MODFLOW was intended to be used for simulating features such as agricultural drains (McDonald and Harbaugh 1988). However, the package has recently been used by others (Quinn and Tomasko 2000; Quinn et al. 1998, 2005, 2006 ) to simulate flow in karstic channels. We have used this technique to simulating flow through the karstic features at our study areas because we believe that it accurately reproduces the karstic system's responses to system input and output. MODFLOW characterizes the drain channels in individual model cells by using two parameters, elevation and conductance. Water is removed from the model cells via the drains at a rate proportional to the difference between the head in the surrounding matrix and the drain elevation, the length of a drain within a cell, and the assigned conductance. This description of flow is significantly different from the cubic law for flow in conduits, which is proportional to the hydraulic gradient along the flowpath. For transient flow, the storativity of the conduits is conspicuously absent when flow is governed by the Drain Package module. The assumptions implied by 


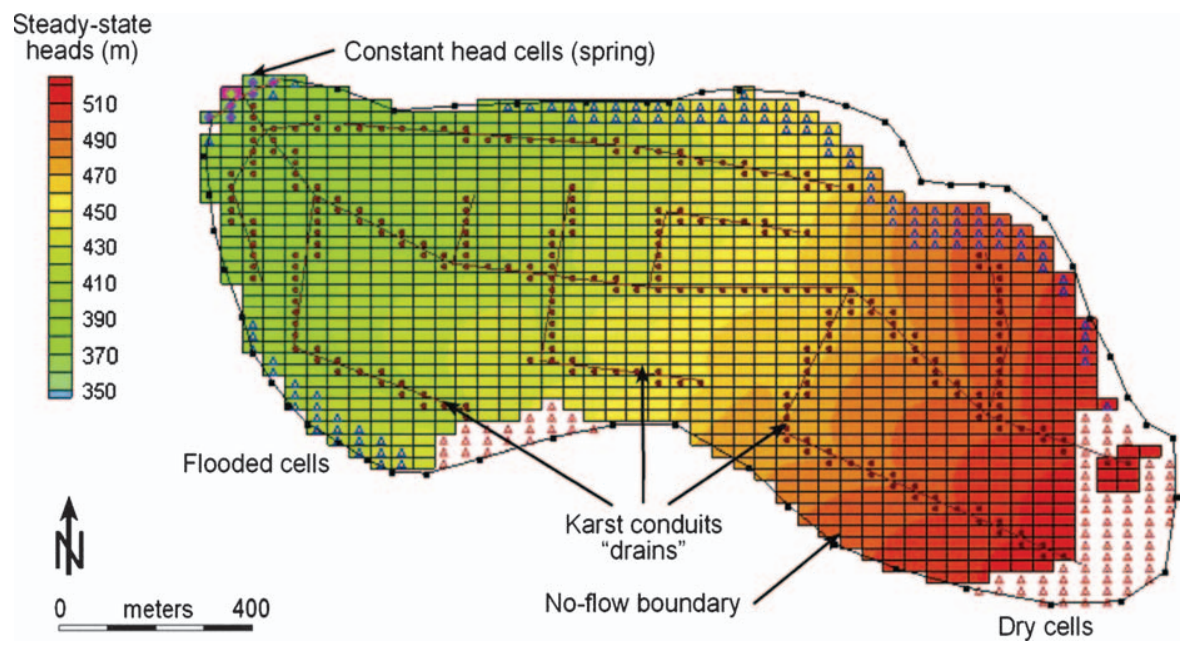

Figure 6. Map view of the numerical model at Ein Al Matwi. Steady-state simulation of ground water levels is shown.

using the Drain Package are considered to be among the other unsupported approximations commonly made regarding the mathematical description of hydraulic behavior in fractured aquifers (Angelini and Dragoni 1997). Among the approximations regarding karst conduits, which will also have a direct impact on the effective hydraulic conductivity, are permeability variation with depth, scaling effects, connectivity, and geometric positioning (orientation, intensity, and size) within the flow model. Furthermore, because flow in conduits may be turbulent, it may be inappropriate altogether to speak of a conduit hydraulic conductivity (White 2003).

The size and intensity of the karst conduits was maintained constant between each of the models by keeping the same ratio of total area of drain cells to total model area $(24.7 \%)$. In each model, the drain heights above the aquitard were also kept relatively constant $(\sim 5 \mathrm{~m})$. The orientations of the drains in the model were aligned to generally conform with fracture lineations observed on field outcrops and air photos with all of the drains eventually leading to the spring. Each of the modeled study areas have only one spring. Drains were laid out over the 2D model area with relatively constant spacing. However, individual drain lengths generally matched the lineation lengths observed on the air photos.

Digital elevation maps at a resolution of $25 \mathrm{~m}$ were used for defining the boundaries of each model. Geologic maps at a scale of 1:50,000 were used in conjunction with field surveys for establishing the strike and dip of the model layers (Figure 4 and Figures S1 through S3). The "Interpolation to MODFLOW Layers" command was used to establish the correct (dipping) elevation of the perched aquifer base.

Transient flow simulations were based on a time series of transient recharge, $R(t)$, derived from measured precipitation data near each of the study areas (Figure 5 and Figures S5 through S7). The daily precipitation data were translated into daily recharge data by using two techniques. The first technique was based on the series of linear equations discussed aforementioned (Guttman 2000). The second technique was based on trial and error calibration to minimize the difference between the simulated and the measured spring discharge hydrographs as discussed subsequently.

A FORTRAN program was written to extract the pertinent simulation results from the MODFLOW output file. The code extracted flux data from three sources of the simulated model: (1) flux through drains; (2) flux through the constant-head cells in the upper layer near the spring; and (3) flux through the constant-head cells in the lower layer. The sum of the first two fluxes represents the total discharge from the spring from both the matrix and the karst conduit sources. The third flux represents the amount of water that penetrates to the lower aquifer. In addition, flux data of storage changes, recharge, and the number of dry cells were extracted from the output file in order to check the mass balance error of each simulation.

\section{Calibration Methodology}

Model calibration efforts focused mainly on the transient distribution of recharge, $R(t)$, while estimation of the hydraulic conductivity of the rock matrix and fractures, as well as the storativity, was secondary. By doing so, we were able to calculate functions describing the relationship between precipitation and aquifer recharge for each of the study sites. Of course, there is no single unique solution; however, we will show that the inverse methods used for estimating the recharge distribution (and hydraulic conductivity to a lesser extent) based on accurate and lengthy spring discharge data as well as a well-defined spring recharge area provide well constrained estimates for these parameters and serve as an excellent means for calibrating the flow model.

The five main model parameters that needed to be adjusted during the calibration process were (1) recharge, $R(t)$; (2) horizontal hydraulic conductivity in the perched layer, $K_{\mathrm{h}}$; (3) vertical hydraulic conductivity in the aquitard, $K_{\mathrm{v}}$; (4) storativity in the perched layer, $S_{1}$; and (5) drain conductance, $C_{\mathrm{d}}$. The main task during the calibration process was to fit the simulation results to the observed data (i.e., spring hydrographs) using elementary 
statistical techniques while keeping the model parameters within certain predefined bounds of prior information. Unfortunately, no head data were available in any of the study sites. Calibration was carried out by comparing the spring hydrographs to the model simulations on two levels. The first level compared the integral of the entire time of the hydrograph to the integral of the entire time of the model simulation results (15 to 28 years). For instance, at Ein Delbah, the spring hydrograph total observed discharge for the entire modeled time period of 26 years was $946,812 \mathrm{~m}^{3}$. The corresponding flow for the model simulation hydrographs was also calculated and the difference between the two was minimized. The second level of calibration compared the integral of the spring hydrograph data to the model simulation results over 12-month time spans. This allowed us to increase the accuracy of our calibration. Spring hydrograph data were generally recorded monthly and the model simulations were also constructed to give monthly output. The error minimized is expressed by the following equation:

$$
\% \text { error }=100 \times\left(\frac{\left|\int_{0}^{t} Q_{\text {spring }} \mathrm{d} t-\int_{0}^{t} Q_{\text {simulation }} \mathrm{d} t\right|}{\int_{0}^{t} Q_{\text {spring }} \mathrm{d} t}\right)
$$

where $Q$ is the discharge and $t$ is the time length of both the spring discharge data and the corresponding model.

Calibration efforts also attempted to fit the simulated model to the following characteristics of the spring hydrograph and field data: (1) the baseline of the hydrographs; (2) the peaks of the hydrographs; and (3) the mass balance calculations showing the expected ratio of spring discharge to the overall recharge. The baseline calibration was considered to be a stringent parameter since the baseline flow exists 12 months out of the year. Peak calibration was also considered important, although in some cases it was difficult to replicate accurately. The field techniques used to measure spring discharge (bucket and stopwatch) make the measurement of high spring discharges (more than $30 \mathrm{~L} / \mathrm{s}$ in many cases) difficult and prone to error. Furthermore, monthly measurements may miss the true discharge peak of karst springs. Therefore, we considered the hydrograph peaks as secondary to the baseline conditioning.

The prior information we have regarding the discharge-recharge ratio is dependent on the defined recharge area, which is very accurate owing to the obvious field exposure of the geologic boundaries.

An important point regarding calibration of the numerical flow models is the typical phenomenon of the Israeli semiarid climate to cycle back and forth every 5 to 10 years between a sequence of relatively rainy years and drought years. Depending on the storage properties of the unsaturated zone, the perched aquifer has both a shortterm "memory" of the immediately preceding year and a longer-term memory of the previous years and cycles. This can be observed in the transient trend of the spring discharge and we tried to replicate these intermediaterange cyclic trends during the calibration process of our models. Karst channeling at the study area is well developed near the surface (some even allow deep entry to humans) and spring discharge responds rapidly (hours to days) to precipitation events, suggesting that storage properties in the unsaturated zone are a secondary issue.

\section{Model Simulation Results}

Figures 7 through 10 show the simulation results for each of the study areas. The results shown are based on the transformation of the measured precipitation data to recharge data according to trial and error in order to minimize the error (Equation 2) between the simulation results and the spring discharge hydrographs. Each of the figures shows the actual spring discharge data along with the "best-fit" model simulation results.

The figures show how the model simulations replicate the transient spring hydrograph data for the various study areas over a significant time period. Both seasonal variations and intermediate-range multiyear variations are simulated by the models. The latter is particularly evident in the example from Ein Al Matwi, where from 1974 to 1978 (and to a lesser extent from 1982 to 1985) the gradual decrease in spring discharge is closely reconstructed.

Table 2 shows the model parameter values derived inversely for the best-fit simulations: horizontal hydraulic conductivity of the perched aquifer, $K_{\mathrm{h}}$; vertical hydraulic conductivity of the aquitard, $K_{\mathrm{v}}$, storativity of the perched aquifer, $S_{1}$; and the drain conductance, $C_{\mathrm{d}}$. The storativity value assigned to the perched aquifer represents the rock matrix under unconfined conditions. In this case, water is removed from storage mainly by gravity drainage and the specific yield is a good approximation of the storativity (Fetter 1988). In all of the models, a value of 0.05 was assigned for the storativity of the (nonfractured) aquifer matrix, which is consistent with the results of water well drilling surveys in the limestone and dolomite Judea Group that shows low yield outside of fractured zones. Independent verification (below) based on ground water chemistry and hydrograph recession analyses was conducted to confirm these low values. The other parameters were defined based on multiple simulations to derive the best combinations for the particular model. A sensitivity

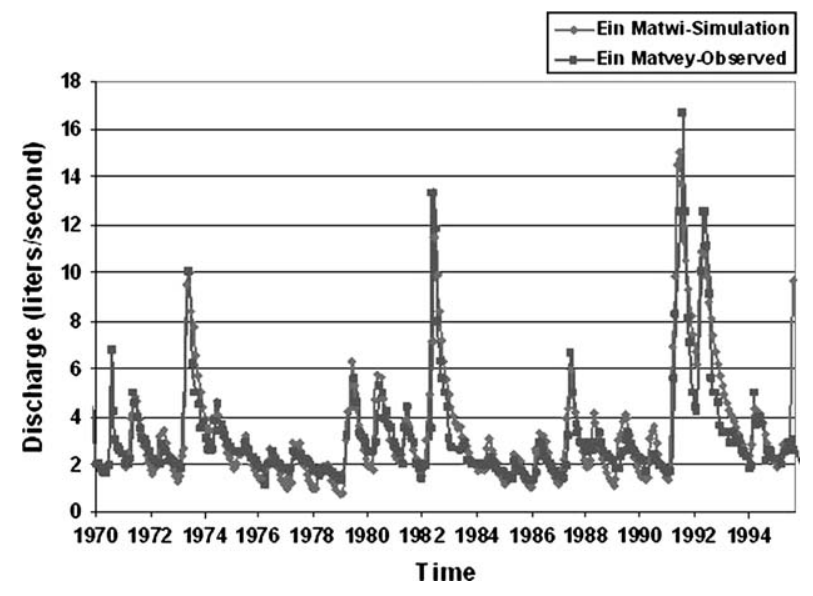

Figure 7. Hydrograph data from Ein Al Matwi and MODFLOW simulation results. 


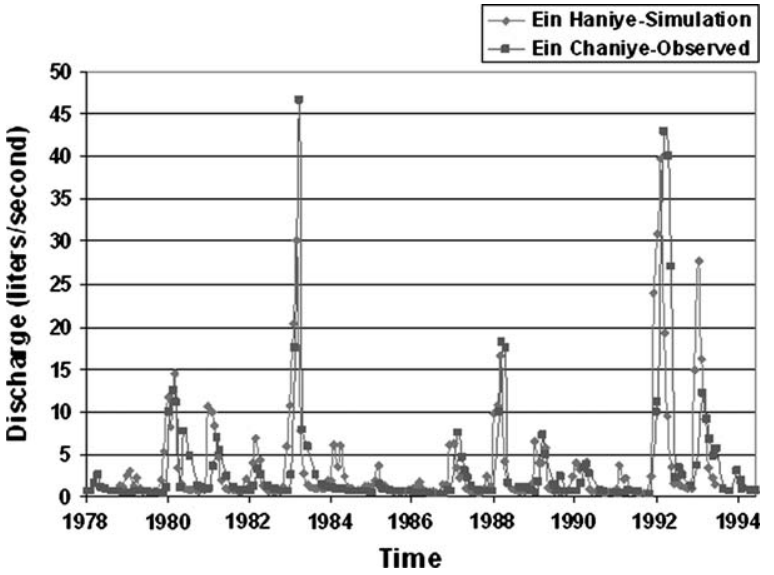

Figure 8. Hydrograph data from Ein Haniye and MODFLOW simulation results.

analysis was conducted (see electronic supplementary material with Figures S8 through S11) to determine the relative effects of varying the parameters. The drain conductance values for all of the models were the same (1.00 $\mathrm{m}^{2} / \mathrm{d} / \mathrm{m}$ ) except for Ein Al Matwi, which required a smaller value $\left(0.02 \mathrm{~m}^{2} / \mathrm{m} / \mathrm{d}\right)$ in order to achieve appropriate results. We assume that the reason for this is an actual change in the fracture characteristics (decrease in size, intensity, and/or aperture) that is actual field heterogeneity. The horizontal hydraulic conductivity values in the perched aquifer range nearly one and a half orders of magnitude from 0.004 to $0.01 \mathrm{~m} / \mathrm{d}$. The vertical hydraulic conductivity values in the aquitard range from $1.3 \times 10^{-6}$ to $2.2 \times 10^{-4} \mathrm{~m} / \mathrm{d}$ based on a constant thickness of $50 \mathrm{~m}$ for all of the sites.

The trial and error, best-fit technique to characterize transient recharge, $R(t)$, allowed us to estimate the precipitation-recharge function for each year and for each of the four study areas as shown in Table 3 and Figure 11. As can be seen, the polynomial precipitation-recharge functions derived from the numerical modeling efforts deviate from Guttman's series of three linear equations. The results also show that recharge can vary from less

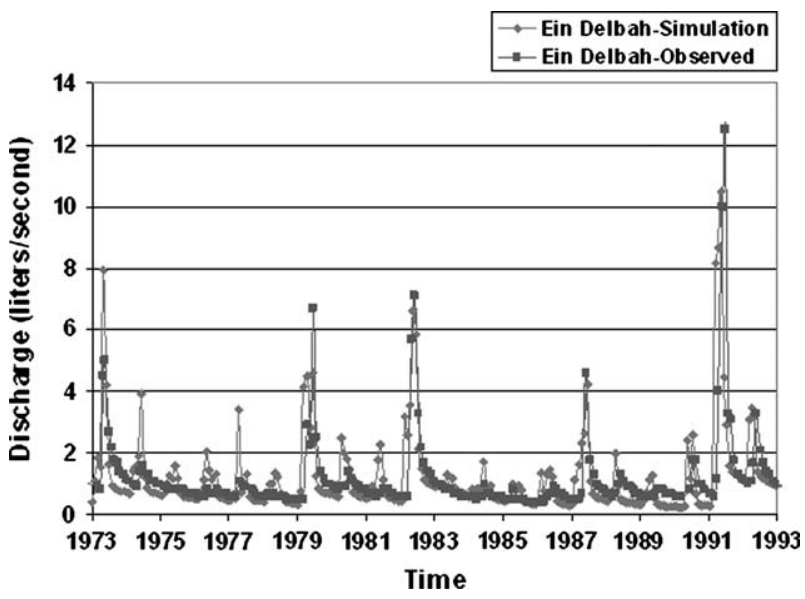

Figure 9. Hydrograph data from Ein Delbah and MODFLOW simulation results.

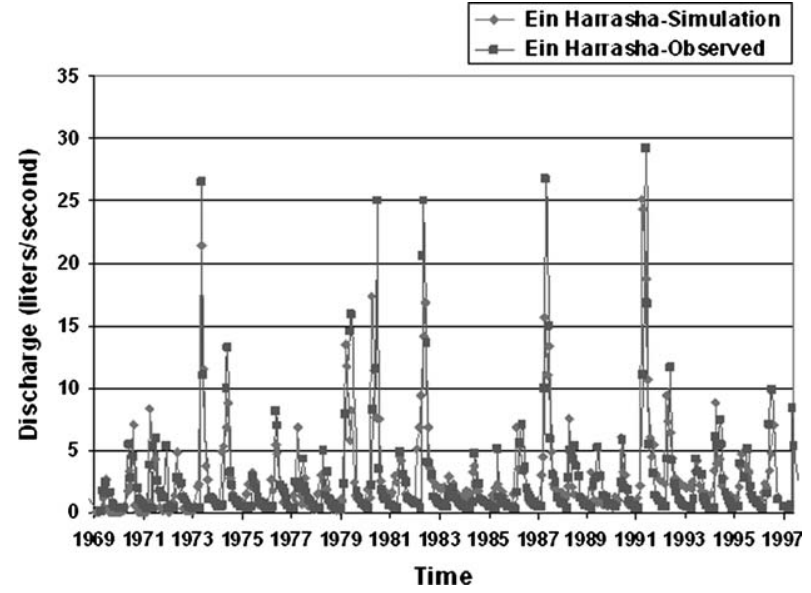

Figure 10. Hydrograph data from Ein Harrasha and MODFLOW simulation results.

than $10 \%$ of precipitation in or during the course of a few very dry years to greater than $80 \%$ of precipitation in or during the course of a few very wet years. The results from Ein Harrasha deviate from the three other functions, and we suggest that this probably results from the different hydrogeologic conditions at this spring. The Kefira Formation probably allows more recharge to infiltrate into the subsurface than the Amminadav Formation due to its karstic character. The Kefar Sha'ul Formation is nonkarstic, and, therefore, less recharge occurs in the other three catchment basins where these rocks exist. An inspection of the simulation results (not shown here) reveals that vertical hydraulic conductivity values less than this produce simulated hydrographs with very high baselines, very high peak discharges, and a very high percentage (60\% plus) of recharge water being discharged from the spring. In some cases, major portions of the MODFLOW grid become flooded. Because of this, we believe that the variation of the precipitation-recharge function for Ein Harrasha from the other study areas is a realistic variation due to hydrogeologic heterogeneity between the various perched aquifers.

The polynomial functions produced from the numerical modeling efforts also show that the Guttman relationship may overestimate recharge to the aquifer, at least for years where the yearly precipitation is below approximately $0.95 \mathrm{~m}$. For years with higher rainfall, there are fewer data; however, the Guttman approximation may then underestimate the actual recharge. The Guttman function appears to underestimate the recharge for the rainfall in the Ein Harrasha study area.

\section{Independent Verifications}

\section{Using Chloride Concentrations}

Recharge rates to unconfined aquifers can be calculated by using simple budget models of a conservative tracer such as chloride (Macfarlane et al. 2000), where quantification of ground water recharge is made by comparing the relative mass of chloride in rain with spring water. The extent of chloride enrichment in the spring 
Table 2

Best-Fit Hydraulic Parameters and Error Associated with Model Calibration

\begin{tabular}{|llllc|}
\hline & Ein Al Matwi & Ein Haniye & Ein Delbah & Ein Harrasha \\
\hline$K_{\mathrm{h}}(\mathrm{m} / \mathrm{d})$ & 0.01 & 0.001 & 0.004 & 0.004 \\
$K_{\mathrm{v}}(\mathrm{m} / \mathrm{d})$ & $2.2 \times 10^{-4}$ & $1.9 \times 10^{-6}$ & $1.3 \times 10^{-6}$ & $3.9 \times 10^{-6}$ \\
$S_{1}$ & 0.05 & 0.05 & 0.05 & 0.05 \\
$C_{\mathrm{d}}\left(\mathrm{m}^{2} / \mathrm{d} / \mathrm{m}\right)$ & 0.02 & 1.00 & 1.00 & 1.00 \\
Overall error \% (recharge characterized & 97.0 & 31.6 & 34.2 & 71.7 \\
$\quad$ according to Guttman [2000]) & 6.7 & 1.3 & 5.8 & 2.8 \\
Overall error \% (recharge characterized & & & \\
$\quad$ according to a trial and error best fit) & & & \\
\hline
\end{tabular}

water is assumed to result from evapotranspiration only (Eriksson and Khunakasem 1969). Our study areas are relatively barren of soil horizons, so there is very limited soil-water interaction for potential chloride enrichment. We examined the chloride enrichment in order to independently verify the recharge rates we obtained using the ground water modeling efforts described aforementioned. The recharge rate can be calculated as:

\begin{tabular}{|c|c|c|c|c|}
\hline \multicolumn{5}{|c|}{$\begin{array}{c}\text { Table } 3 \\
\text { Results of Model Calibration to Define } \\
\text { Precipitation-Recharge Functions }\end{array}$} \\
\hline Year & $\begin{array}{l}\text { \% Recharge } \\
\text { Ein Al } \\
\text { Matwi }\end{array}$ & $\begin{array}{c}\text { \% Recharge } \\
\text { Ein } \\
\text { Haniye }\end{array}$ & $\begin{array}{l}\text { \% Recharge } \\
\text { Ein } \\
\text { Delbah }\end{array}$ & $\begin{array}{l}\text { \% Recharge } \\
\text { Ein } \\
\text { Harrasha }\end{array}$ \\
\hline 1970 & NA & NA & NA & 49 \\
\hline 1971 & NA & NA & NA & 64 \\
\hline 1972 & 29 & NA & NA & 55 \\
\hline 1973 & 28 & NA & NA & 42 \\
\hline 1974 & 43 & NA & 42 & 70 \\
\hline 1975 & 13 & NA & 27 & 54 \\
\hline 1976 & 20 & NA & 18 & 26 \\
\hline 1977 & 19 & NA & 19 & 52 \\
\hline 1978 & 26 & NA & 22 & 43 \\
\hline 1979 & 26 & 13 & 16 & 37 \\
\hline 1980 & 36 & 28 & 38 & 83 \\
\hline 1981 & 30 & 34 & 22 & 83 \\
\hline 1982 & 20 & 21 & 18 & 24 \\
\hline 1983 & 45 & 44 & 41 & 87 \\
\hline 1984 & 6 & 26 & 9 & 10 \\
\hline 1985 & 20 & 10 & 14 & 25 \\
\hline 1986 & 20 & 7 & 12 & 24 \\
\hline 1987 & 25 & 20 & 18 & 42 \\
\hline 1988 & 31 & 35 & 31 & 91 \\
\hline 1989 & 29 & 24 & 17 & NA \\
\hline 1990 & 32 & 19 & 17 & NA \\
\hline 1991 & 29 & 15 & 27 & 48 \\
\hline 1992 & 56 & 56 & 54 & 77 \\
\hline 1993 & 33 & 52 & 22 & 30 \\
\hline 1994 & 1 & NA & 14 & 16 \\
\hline 1995 & 18 & NA & 25 & 33 \\
\hline 1996 & 16 & NA & NA & 32 \\
\hline 1997 & NA & NA & NA & 29 \\
\hline Average & 26.0 & 26.9 & 23.8 & 47.2 \\
\hline
\end{tabular}

$$
R=\frac{\mathrm{Cl}_{\mathrm{r}}}{\mathrm{Cl}_{\mathrm{s}}}
$$

where $\mathrm{Cl}_{\mathrm{r}}$ is the chloride deposition rate from rain and $\mathrm{Cl}_{\mathrm{s}}$ is the chloride concentration in the spring water.

Chloride concentrations in rain throughout each of the study areas are constant (10.2 mg/L) (Rosenthal 1987), while the average annual precipitation for each of the study areas varies (Table 1). Multiplying the two gives $\mathrm{Cl}_{\mathrm{r}}$, the chloride deposition rate from rain (Table 4) assuming 1000 $\mathrm{L}$ of rain in a cubic meter. Data on chloride concentrations in the various spring water are also shown in Table 4 as are the resulting recharge rates (expressed as a percentage of the average annual precipitation) derived from the ground water modeling exercises and the independent verification based on chloride enrichment.

The results show that the recharge values derived from the chloride enrichment calculations are very similar to the recharge values determined from calibration of the ground water flow models. These results suggest that the models developed for each of the sites accurately portray the ground water flow systems.

\section{Using Spring Recession Curves}

The recession curves from the spring discharge data were analyzed to determine the storage properties of the various perched aquifers. Following Amit et al. (2002), the recession curves were treated as being composed of two primary components, quick flow from the karstic ground water pathways and base flow from the rock matrix (Figure 12). The analyses allowed us to approximate the storage volume at each of the sites and thus the storativity. We compared these values with the saturated rock volumes generated during the MODFLOW simulations from each of the sites. By doing so, we were able to determine the percentage of rock matrix that must be available for storage in each of the simulations to derive the storage volumes observed from the recession curves. In all cases, the calculated storativity in the simulations would have to be less than 0.02 to correlate with the recession curve data. This suggests that the final storativity values used in the calibrated simulations $(0.05)$ are reasonable. Although we tried using smaller (and larger) storativities in the simulations, we found that 0.05 was 


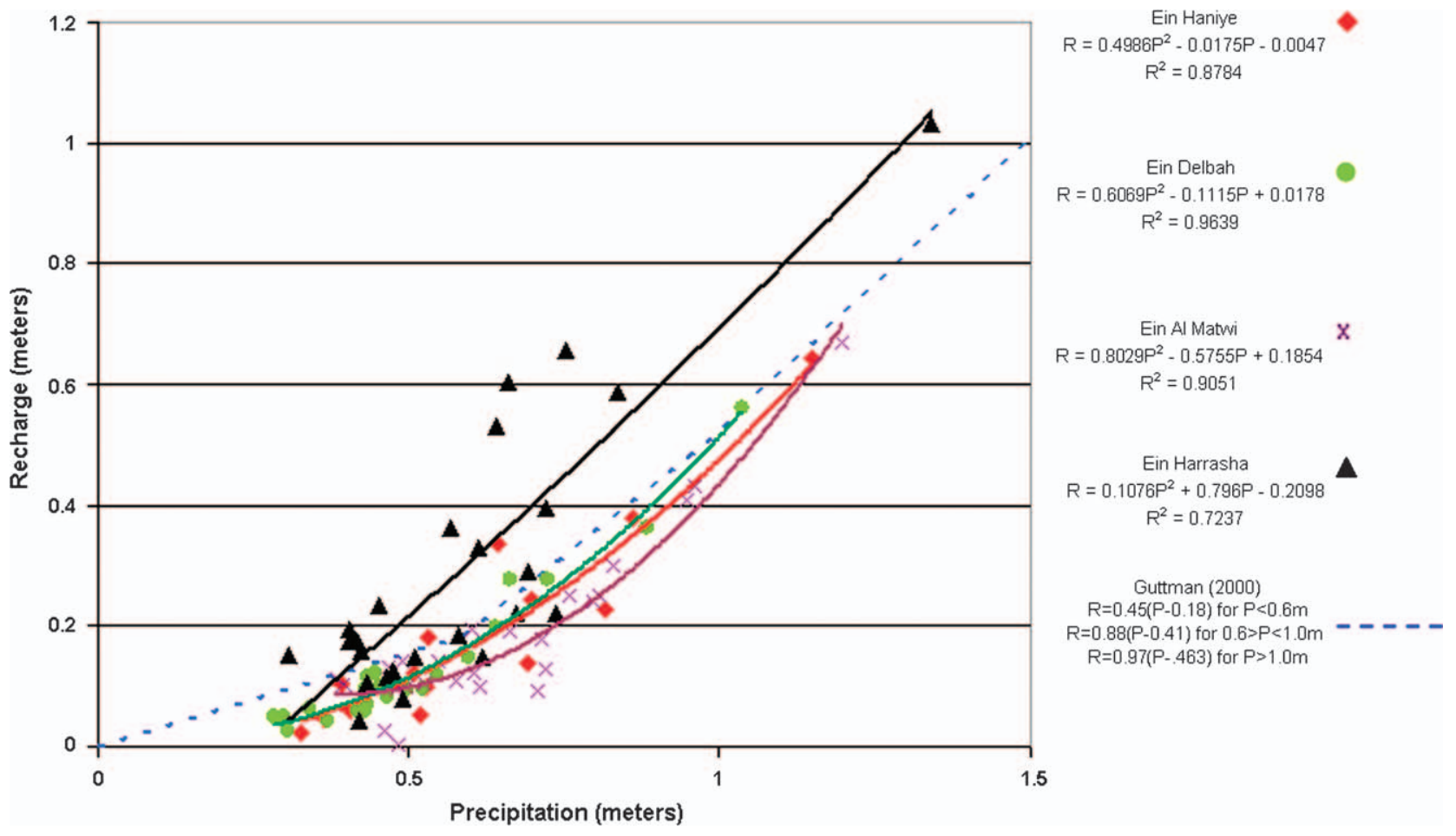

Figure 11. Precipitation-recharge functions developed through inverse modeling efforts; $R=$ recharge and $P=$ precipitation.

the most appropriate storativity value considering all of the various calibration parameters and their effects on the modeling results.

\section{Conclusions}

Numerical modeling allowed us to estimate the precipitation-recharge functions for a number of relatively small-scale study areas in the Yarqon-Taninim aquifer, Israel. The functions are smooth polynomial relationships that differ from previously developed equations. These previously developed equations may have overestimated the actual recharge during years with precipitation lower than $0.95 \mathrm{~m}$ and underestimated the recharge during years with precipitation greater than $0.95 \mathrm{~m}$. One of the study areas tends to exhibit significantly higher recharge because of factors such as rock type, geomorphology, and extent of fracturing. The precipitation-recharge functions are based on a relatively long-term database of global ground water response, allowing us to make good estimations of the expected yearly recharge.
We simulated the karst conduits using drains, which calculate flow using a noncubic law-based approach. The method is reasonable since the Darcy-based description of flow in a dual-porosity aquifer includes approximations of its own, in particular, failure to incorporate turbulence. The method of drains is a straightforward and easy approach to modeling a dual-porosity flow domain, especially where data are unavailable regarding karst network geometry and hydraulic conductivity. Perched conditions were also simulated innovatively using MODFLOW, which is usually able to treat only saturated conditions. We did this by assigning zero pressure head below the perched layer. This approach allowed ground water to flow exit the model as if it were flowing through the unsaturated zone and into the underlying regional aquifer as it does under field conditions.

Hydrograph data are shown to be an excellent source of information for calibrating the numerical models in our karst aquifer setting. Our database consisted of monthly measurements. However, because of the relatively rapid spring discharge response to rainfall in the

\begin{tabular}{|c|c|c|c|c|}
\hline \multicolumn{5}{|c|}{$\begin{array}{c}\text { Table } 4 \\
\text { Results of Chloride Enrichment Calculations }\end{array}$} \\
\hline Spring Name & $\begin{array}{l}\text { Chloride Deposition } \\
\text { Rate }\left(10^{3} \mathrm{mg} / \mathrm{m}^{2} \cdot \text { year }\right)\end{array}$ & $\begin{array}{c}\text { Chloride Concentration } \\
\text { in Spring Water } \\
(\mathrm{mg} / \mathrm{L})\end{array}$ & $\begin{array}{l}\text { Average Annual } \\
\text { Percent Recharge } \\
\text { (Flow Modeling) }\end{array}$ & $\begin{array}{c}\text { Average Percent } \\
\text { Recharge (Chloride } \\
\text { Enrichment) }\end{array}$ \\
\hline Ein Al Matwi & 6.63 & $35-56$ & 26.0 & 22.6 \\
\hline Ein Haniye & 6.06 & $28-41$ & 26.9 & 32.5 \\
\hline Ein Delbah & 5.21 & $30-62$ & 23.8 & 21.3 \\
\hline Ein Harrasha & 6.01 & $18-28$ & 47.2 & 42.4 \\
\hline
\end{tabular}




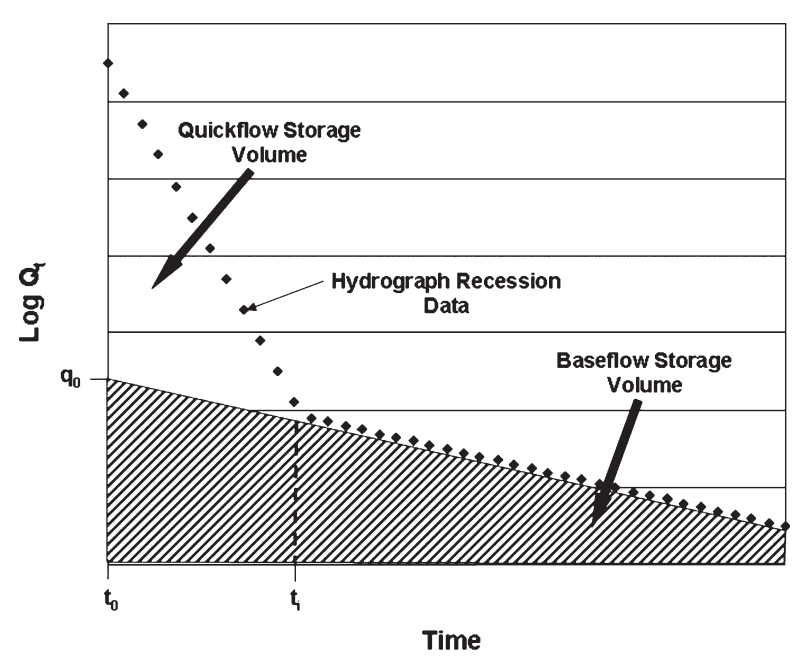

Figure 12. Idealized spring recession curve broken into two flow components; quick flow from fractures/karst and base flow from rock matrix. $t_{0}=$ beginning of recession, $t_{\mathrm{i}}=$ time at which quick flow component ceases, $q_{0}=$ maximum discharge attributable to base flow component alone.

karstic aquifer, it would have been better to have a more detailed database (daily perhaps), especially for the winter months. Recession curve analyses provide little useful information for the model development because although matrix storage may be relatively high, conduit conductivity far outweighs the matrix conductivity and is therefore the primary source of spring discharge even in a dualporosity environment.

Sensitivity analyses show that it is more important to define the recharge parameter accurately than the hydraulic conductivity parameter. Accurately defining recharge has implications not only for the reliability of ground water models and their predictions but also for other disciplines such as geotechnical engineering and agriculture.

The wide variation of climate types, hydrogeologic and hydrostratigraphic structures, land use, and topographic slope and relief within the relatively small area of Israel (size of New Jersey) creates the need for further work to develop and subsequently apply calibrated precipitation-recharge functions to other areas within the country.

\section{Supplementary Material}

The following supplementary material is available for this article:

Figure S1. Topographic and Geological map showing the model boundaries of Ein Haniye. Ground elevations are in meters above sea level.

Figure S2. Topographic and Geological map showing the model boundaries of Ein Delbah. Ground elevations are in meters above sea level.

Figure S3. Topographic and Geological map showing the model boundaries of Ein Harrasha. Ground elevations are in meters above sea level.

Figure S4. Legend for Geologic Maps.

Figure S5. Yearly Precipitation at Ein Haniye.

Figure S6. Yearly Precipitation at Ein Delbah.
Figure S7. Yearly Precipitation at Ein Harrasha.

Figure S8. Sensitivity to Vertical Hydraulic Conductivity in Aquitard. No convergence of numerical model at $\mathrm{K}_{\mathrm{v}}>1.25 \mathrm{e}^{-4} \mathrm{~m} / \mathrm{d}$.

Figure S9. Sensitivity to Extent of Drain Coverage. Not enough memory available to numerical model at drain coverage extent greater than $30.0 \%$.

Figure S10. Sensitivity to Horizontal Hydraulic Conductivity in Perched Aquifer. No convergence of numerical model at $\mathrm{K}_{\mathrm{h}}>0.051 \mathrm{~m} / \mathrm{d}$.

Figure S11. Sensitivity to Drain Conductance.

This material is available as part of the online article from: http://www.blackwell-synergy.com/doi/abs/10.1111/ j.1745-6584.2007.00360.x

(This link will take you to the article abstract).

Please note: Blackwell Publishing is not responsible for the content or functionality of any supplementary materials supplied by the authors. Any queries (other than missing material) should be directed to the corresponding author for the article.

\section{Acknowledgments}

The authors thank Ground Water Editor Mary P. Anderson, Dr. John Quinn, Dr. William Anderson Jr., Dr. Randy Hunt, and one anonymous reviewer for their constructive advice, which significantly improved this article. We thank the Israeli Water Commission for their financial assistance, Professor H. Blatt and Professor A. Frumkin for their comments on the manuscript, and Mr. J. Steinberg for his assistance with the figures.

\section{References}

Amit, H., V. Lyakhovsky, A. Katz, A. Starinsky, and A. Burg. 2002. Interpretation of spring recession curves. Ground Water 40, no. 5: 543-551.

Angelini, P., and W. Dragoni. 1997. The problem of modeling limestone springs: The case of Bagnara (north Apennines, Italy). Ground Water 35, no. 4: 612-618.

Arkin, Y. 1976. Geologic Map of Israel, Jerusalem and Vicinity 1:50,000. Jerusalem, Israel: State of Israel Geologic Survey.

Bar-Mathews, M., and A. Ayalon. 1988. Mineralogical and petrologic research of sediments in the Soreq cave, Beit Shemesh, Jerusalem. Report No. 88/3. Jerusalem, Israel: Israel Geologic Survey (in Hebrew).

Bida, A. 1986. The Yarqon-Taninim basin and the mountain aquifer. In Transcripts from the Conference of the Israel Association of Water Resources and Ministry of Science. 51-57. Jerusalem, Israel: Israel Association of Water Resources and Ministry of Science.

Burg, A. 1998. Geochemistry and hydrology of perched carbonate aquifers in northern and central Israel. Ph.D. thesis, Institute of Earth Sciences, Hebrew University of Jerusalem, Israel.

Eriksson, E., and V. Khunaksem. 1969. Chloride concentration in ground water, recharge rate and rate of deposition of chloride in the Israel coastal plain. Journal of Hydrology 7, no. 2: 178-197.

Fetter, C.W. 1988. Applied Hydrogeology, 2nd ed. Columbus, Ohio: Merrill Publishing Company.

Flint, A.L., L.E. Flint, E.M. Kwicklis, J.T. Fabryka-Martin, and G.S. Bodvarsson. 2002. Estimating recharge at Yucca 
Mountain, Nevada, USA: Comparison of methods. Hydrogeology Journal 10, no. 1: 180-204.

Frumkin, A. 2002. The hydrogeology of Israel and the problem of water supply in antiquity. Journal of Roman Archaeology SS 46, 21-24.

Frumkin, A., and I. Fischhendler. 2005. Morphometry and distribution of isolated caves as a guide for phreatic and confined paleohydrological conditions. Geomorphology 67, no. 3-4: 457-471.

Guttman, J. 2000. Multi-Lateral Project B: Hydrogeology of the Eastern Aquifer in the Judea Hills and Jordan Valley. Report No. 468. Tel Aviv, Israel: Mekorot Water Company.

Guttman, J. 1986. Hydrogeology of the Judean aquifer in the southern Hebron hills, Arad basin and Beer Sheva. Report No. 01/86/2. Tel Aviv, Israel: Tahal Consulting Engineers Ltd. (in Hebrew).

Guttman, J., and H. Zuckerman. 1995. Flow model in the eastern basin of the Judea and Samaria hills. Report No. 01/95/ 66. Tel Aviv, Israel: Tahal Consulting Engineers Ltd. (in Hebrew).

Gvirtzman, H. 2002. Israel Water Resources, chapters in hydrology and environmental sciences. Jerusalem, Israel: Yad Ben-Zvi Press (in Hebrew).

Harbaugh, A.W., E.R. Banta, M.C. Hill, and M.G. McDonald. 2000. MODFLOW-2000, the U.S. geological survey modular ground-water model-user guide to modularization concepts and the ground-water flow process. USGS Open-File Report 00-92. Reston, Virginia: USGS.

Hydrology Service. 2005. Development and status of Israel's water resources as of fall 2004. Report from Office of National Infrastructure (in Hebrew). Jerusalem, Israel: Moshe Ganot.

Hydrology Service. 2001. Development and status of Israel's water resources as of fall 2000. Report from Office of National Infrastructure (in Hebrew). Jerusalem, Israel: Moshe Ganot.

Macfarlane, P.A., J.F. Clark, M.L. Davisson, G.B. Hudson, and D.O. Whittemore. 2000. Late-quaternary recharge determined from chloride in shallow groundwater in the central great plains. Quaternary Research 53, no. 2: $167-174$.

McDonald, M.G., and A.W. Harbaugh. 1988. Techniques of water-resources investigations of the United States geological survey; Chapter superseding. USGS Report No. 83875. Reston, Virginia: USGS.

Mercado, A. 1980. Groundwater salinity in the Beer Sheva Basin, Yarqon-Taninim. Report No. 01/80/60. Tel Aviv, Israel: Tahal Engineering Consultants Ltd. (in Hebrew).
Nimmo, J.R., R.W. Healy, and D.A. Stonestrom. 2005. Aquifer recharge. In Encyclopedia of Hydrological Science, ed. M.G. Anderson and J. Bear, vol. 4, 2229-2246. Chichester, UK: Wiley.

Padilla, A., A. Pulido-Bosch, and A. Mangin. 1994. Relative importance of baseflow and quickflow from hydrographs of karst spring. Ground Water 32, no. 2: 267-277.

Quinn, J., and D. Tomasko. 2000. A numerical approach to simulating mixed flow in karst aquifers. In Groundwater Flow and Contaminant Transport in Carbonate Aquifers, ed. I. Sasowsky and C. Wicks, 147-156. Rotterdam, Holland: A.A. Balkema.

Quinn, J.J., D. Tomasko, and J.A. Kuiper. 2006. Modeling complex flow in a karst aquifer. Sedimentary Geology 184, no. 3-4: 343-351.

Quinn, J.J., D. Tomasko, and J.A. Kuiper. 2005. The role of MODFLOW in numerical modeling of karst flow systems. In U.S. Geological Survey Karst Interest Group Proceedings, Rapid City, South Dakota, ed. E. L. Kuniansky, 58-62. USGS Scientific Investigations Report 2005-5160. Reston, Virginia: USGS

Quinn, J.J., D. Tomasko, M.A. Glennon, S.F. Miller, and L.D. McGinnis. 1998. Using MODFLOW drains to simulate groundwater flow in a karst environment. In Proceedings of MODFLOW' '98, 105-112. Golden, Colorado: International Ground Water Modeling Center.

Rosenthal, E. 1987. Chemical composition of rainfall and groundwater in recharge areas of the Bet Shean-Harod multiple aquifer system, Israel. Journal of Hydrology 89, no. 3-4: 329-352.

Sanford, W. 2002. Recharge and groundwater models: An overview. Hydrogeology Journal 10, no. 1: 110-120.

Scanlon, B.R., and P.G. Cook. 2002. Preface theme issue on groundwater recharge. Hydrogeology Journal 10, no. 1: 3-4.

Scanlon, B.R., S.W. Tyler, and P.J. Wierenga. 1997. Hydrologic issues in arid systems and implications for contaminant transport. Reviews of Geophysics 35, no. 4: 461-490.

Shachnai, E. 2000. Geologic Map of Israel, Ramallah 1:50,000. Jerusalem, Israel: State of Israel Geologic Survey.

Sneh, A., Y. Bartov, and M. Rosensaft. 1998. Geologic Map of Israel, Sheet 2 1:200,000. Jerusalem, Israel: State of Israel Geologic Survey.

White, W.B. 2003. Conceptual models for karst aquifers. Speleogenesis and Evolution of Karst Aquifers 1, no. 1: 1-6.

Worthington, S.R.H. 2003. A comprehensive strategy for understanding flow in carbonate aquifers. Speleogenesis and Evolution of Karst Aquifers 1, no. 1: 1-8. Re-published from: Karst Modeling: Special Publication 5, ed. A.N. Palmer, M.V. Palmer, and I.D. Sasowsky, 30-37. Charles Town, West Virginia: The Karst Waters Institute. 